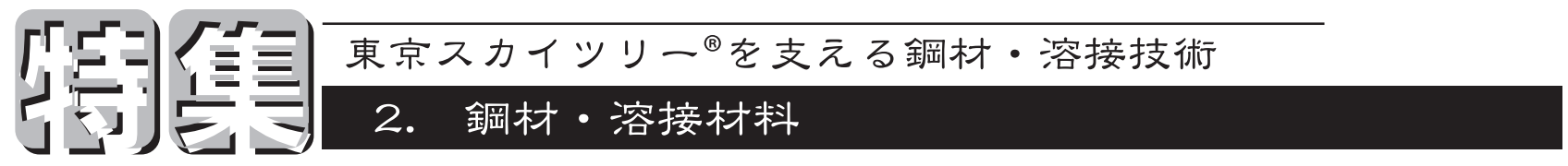

\title{
2.3 溶接材料
}

\section{東京スカイツリー建設工事に使われた溶接材料 ${ }^{*}$}

\section{村田 義明 $^{* *}$, 豊田 剛正 ${ }^{* * *}$}

\author{
Welding Consumables used for Construction of Tokyo Sky Tree ${ }^{*}$ \\ by MURATA Yoshiaki $^{* *}$ and TOYODA Takamasa ${ }^{* * *}$
}

キーワード＼cjkstart東京スカイツリー，溶接材料，塔体，外周架構，ゲイン塔，分岐継手，高降伏点鋼，鋼管

\section{1.はじめに}

2012年 5 月に開業した東京スカイッリー（以下，本タワ 一）は，全高 $634 \mathrm{~m}$ の地上波デジタル放送を担う自立式電 波塔として，多くの新しい技術が投入され，2008年 7 月の 着工から 2012 年 2 月末の竣工まで, 約 3 年半を費やして建 設された。また，本タワーの確認申請区分は工作物内建築 物で，建築物としての高さは $459 \mathrm{~m} （$ 軒高 $=459.42 \mathrm{~m} ）$ であ り，横浜ランドマークタワーの $296 \mathrm{~m}$ を上回り，建築物と しても日本一の高さを誇っている.

本タワーの建設工事においては,

(1)各種の高強度・厚肉鋼管を採用

(2)鋼管トラス構造とするため, 各鋼管の連結部には分岐 継手を採用

(3)現場工事では未曾有の高所作業となる などの特色があった。

本タワー建設工事で使用された溶接材料には, 鋼管を製 造するためのサブマージアーク溶接材料, 分岐継手や工事 現場継手などの組立てに用いるガスシールドアーク溶接 用のソリッドワイヤとフラックス入りワイヤがある.

本稿では, 上記11)各種高強度鋼管を対象とした溶接材料 の一例，および特長などについて紹介する1-3).

\section{2. 東京スカイツリーの構造と製作フロー}

構造的には, 頂部に位置しアンテナが設置されるゲイン 塔と，これと展望台を支える塔体に大別される.

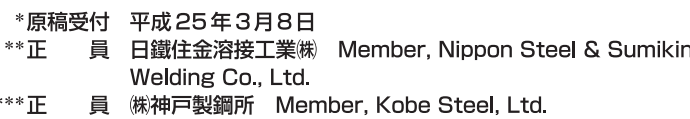

**正 員 (侏神戸製鋼所 Member, Kobe Steel, Ltd.

塔体の構造として，中心にある避難階段を兼ねた鉄筋コ ンクリート製コア（以下，心柱）とエレベータ昇降通路と なるシャフト部を取り囲むように, 鋼管トラス構造の外周 架構が設置され, 心柱と外周架構とが協働して大地震や強 風時の摇れが抑制される制振構造となっている.このよう な大きな外力が作用しても, 弾性を保証する構造のため, 高い応力まで塑性変形しない高降伏点鋼の適用が図られ た.また， $634 \mathrm{~m}$ という高さから外周架構に作用する荷重 は大きく, そのため設計強度 (降伏耐力) が $500 \mathrm{~N} / \mathrm{mm}^{2}$ と $400 \mathrm{~N} / \mathrm{mm}^{2}$ の円形鋼管 (以下，YP500 と YP400 鋼管) が必 要とされた. 最も荷重が大きくなる足元の三角形の頂点に 位置する柱部材には，外形 $2,300 \mathrm{~mm}$, 肉厚 $100 \mathrm{~mm}$ の YP 500 鋼管が採用された.

さらに，ゲイン塔においては，設計強度（降伏耐力）が $630 \mathrm{~N} / \mathrm{mm}^{2}$ のいわゆる HT780 鋼の高強度鋼管が指定され た。ゲイン塔の脚部と本体塔との接続部には，外径 $1,200 \mathrm{~mm}$ ，肉厚 $80 \mathrm{~mm}$ の HT780 鋼管が採用された。

これら高強度，かつ，厚肉の円形鋼管が分岐継手などで 溶接されることで, それぞれ外周架構とゲイン塔の鋼管卜 ラス構造が製作された。製作全体の流れを図 1 に示す.

(1)厚板から鋼管の製造

(2)分岐継手の工場組立て

(3)現場工事（建方)

なお，鋼管の製造（以下，造管）では，肉厚と径に応じ て異なる製造法があるが, 同図は厚肉夕イプの造管に適用 されるプレスベンド鋼管 (以下, $\mathrm{PB}$ 鋼管) の例である.こ れは, 厚板をプレス（一部，ロール曲げ）により円筒形に 成形した後, 継目を溶接してできる鋼管で, その継目の溶 接には, 一般にはサブマージアーク法による多層溶接が適 用されている。

工場および現場の組立てにおいては，主に炭酸ガスシー ルドアーク溶接による半自動溶接法が用いられた。そのな かで，ソリッドワイヤは下向と横向溶接用に適用され，工 場組立てにおいては $1.4 \mathrm{~mm}$ のワイヤ径が，建方では 
$1.2 \mathrm{~mm}$ が主流に使われた. また,フラックス入りワイヤは 全姿勢溶接用として使用された。

\section{3. 外周架構（塔体）の建設工事}

\section{1 高降伏点鋼管について}

塔体の外周架構には，本タワーへの適用を想定して開 発・大臣認定取得作業が進められてきた新しい建築構造

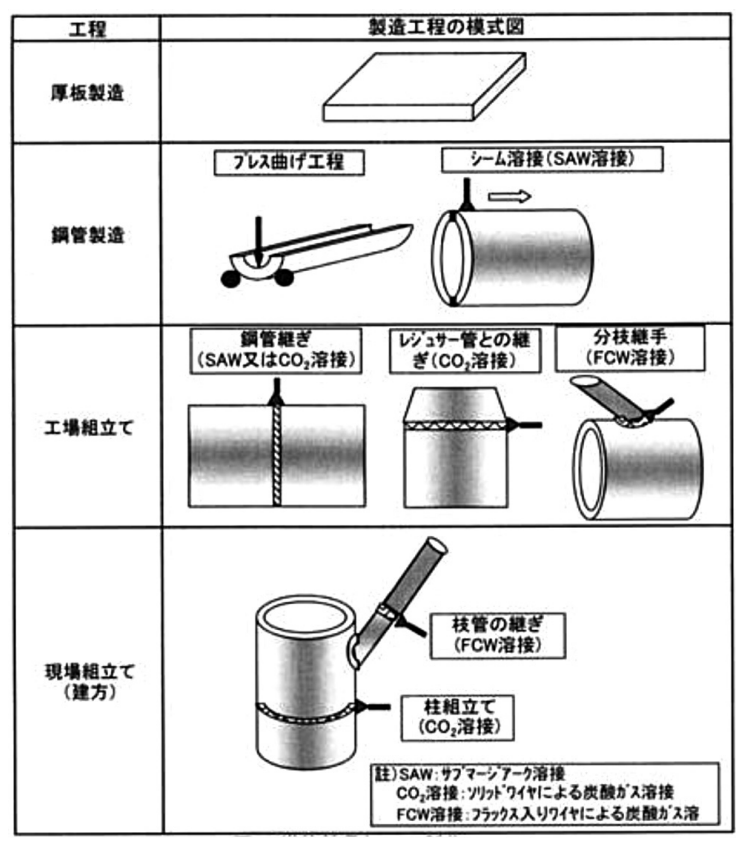

図 1 鋼管トラスの製作フロー
用の YP400, YP500 の円形鋼管が, 柱, 斜材, 水平材とし て大量に使用された (表 1 参照).

一般的に合金を添加して高強度化を行うと, 加工性や溶 接性が損なわれる，そこで，上記鋼管の製作段階から高降 伏点鋼板を素材として使用し, 部材の薄手化による溶接時 間短縮や予熱軽減などが図られた。本鋼材は，圧延工程で の熱加工制御プロセス（TMCP）を活用することで，合金 添加量を抑えるとともに圧延後の熱処理工程を省略又は 軽減して, 結晶粒を微細化して建築構造用鋼材に求められ る溶接性・靫性を確保したまま, 構造設計上の強度である 降伏点を向上させている. 従来の同じ強度クラスの鋼材と 比較して，YP400 鋼管では降伏強さの下限保証值を $23 \%$, YP500 鋼管では 14\% 向上させている.

\section{2 高降伏点鋼管用の溶接材料}

表 2 に示す YP400 および YP500 鋼管用溶接材料は，本 タワー工事で採用された一例である. また，これら製品に 対しては, 前述した高降伏点鋼管のメリットを最大限活用 する観点から，特別仕様が設けられた．以下に，その特長 について解説する.

\section{(1) サブマージアーク溶接材料}

同表に示すサブマージアーク溶接材料は，PB 鋼管の造 管の際，多層溶接に適用される。フラックスとしては，ミ クロ組織微細化技術を活用したTi-B 複合添加タイプを採 用し，溶接金属の高靱性化を図っている。概して，1狭開 先溶接用のスラグ剥離性が良好な溶融フラックス (JIS Z 3352 SFAR1 該当), (2)鉄粉入りボンドフラックス (JIS Z 3352 SFAZ 該当）の 2 種類がそれぞれ採用され, 溶接施工 の能率向上が図られた. 組合せワイヤとしては, 0.1C-2Mn0〜0.5Mo 系の中から，強度レベルに合致したワイヤが選

表 1 外周架構（塔体）に使用された高降伏点鋼管の規格一例

\begin{tabular}{|c|c|c|c|c|c|c|c|c|}
\hline 区分 & 種 類 & $\begin{array}{c}\begin{array}{c}\text { 最大肉厚 } \\
(\mathrm{mm})\end{array} \\
\end{array}$ & $\begin{array}{c}\text { 降伏点 } \\
\left(\mathrm{N} / \mathrm{mm}^{2}\right) \\
\end{array}$ & $\begin{array}{l}\text { 引張強さ } \\
\left(\mathrm{N} / \mathrm{mm}^{2}\right) \\
\end{array}$ & $\begin{array}{c}\text { 降伏比 } \\
(\%) \\
\end{array}$ & $\begin{array}{c}\text { 衝撃値 } \\
(\mathrm{J})\end{array}$ & $\begin{array}{l}P_{C M}{ }^{1)} \\
(\%)\end{array}$ & $\begin{array}{l}\text { 造管 } \\
\text { 方法 }\end{array}$ \\
\hline \multirow{2}{*}{$\begin{array}{l}\text { 高降 } \\
\text { 伏点 }\end{array}$} & YP400 & 60 & $400 \sim 600$ & $490 \sim 640$ & $\leqq 95$ & $\geqq 70\left(0^{\circ} \mathrm{C}\right)$ & $\leqq 0.26$ & UOE, PB \\
\hline & YP500 & 100 & $500 \sim 700$ & $590 \sim 740$ & $\leqq 95$ & $\geqq 70\left(0^{\circ} \mathrm{C}\right)$ & $\leqq 0.30$ & UOE \\
\hline \multirow{2}{*}{ 従来 } & STKN490B & 36 & $325 \sim 475$ & $490 \sim 640$ & $\leqq 80$ & $\geqq 27\left(0^{\circ} \mathrm{C}\right)$ & $\leqq 0.29$ & - \\
\hline & (参) SA440C & - & $440 \sim 540$ & $590 \sim 740$ & $\leqq 80$ & $\geqq 47\left(0^{\circ} \mathrm{C}\right)$ & $\leqq 0.30$ & - \\
\hline
\end{tabular}

表2 スカイツリ一建設工事で使用された高降伏点鋼管用溶接材料の一例

\begin{tabular}{|c|c|c|c|c|c|c|c|c|c|c|c|c|}
\hline \multirow{2}{*}{$\begin{array}{l}\text { 区 } \\
\text { 分 }\end{array}$} & \multirow{2}{*}{ 対象の鋼管 } & \multirow{2}{*}{ 溶接法 ${ }^{1)}$} & \multirow{2}{*}{ 規 格 ${ }^{2)}$} & \multicolumn{6}{|c|}{ 溶着金属の化学成分(\%) } & \multirow{2}{*}{\begin{tabular}{|c|}
$0.2 \%$ 耐力 \\
$\left(\mathrm{N} / \mathrm{mm}^{2}\right)$
\end{tabular}} & \multirow{2}{*}{$\begin{array}{c}\text { 引張強さ } \\
\left(\mathrm{N} / \mathrm{mm}^{2}\right)\end{array}$} & \multirow{2}{*}{$\begin{array}{c}\text { 衝撃値 } \\
(\mathrm{J})\end{array}$} \\
\hline & & & & $\mathrm{C}$ & $\mathrm{Si}$ & $\mathrm{Mn}$ & Mo & 他 & $\mathrm{P}_{\mathrm{CM}}$ & & & \\
\hline \multirow{2}{*}{$\begin{array}{c}\text { 分 } \\
\text { 岐 } \\
\text { 継 } \\
\text { 手 }\end{array}$} & \multirow{2}{*}{$\begin{array}{c}\text { YP400×YP400 } \\
\text { 又は } \\
\text { YP400×YP500 }\end{array}$} & GMAW & $\begin{array}{c}\text { JIS Z } 3312 \\
\text { YGW18 }\end{array}$ & 0.07 & 0.5 & 1.1 & 0.2 & $\mathrm{Ti}, \mathrm{B}$ & 0.19 & 590 & 630 & $\begin{array}{l}150 \\
\left(0^{\circ} \mathrm{C}\right)\end{array}$ \\
\hline & & FCAW & $\begin{array}{c}\text { JIS Z } 3313 \\
\text { T550T1-1CA-X-X }\end{array}$ & 0.05 & 0.4 & 1.2 & 0.3 & - & 0.16 & 560 & 630 & $\begin{array}{c}94 \\
\left(0^{\circ} \mathrm{C}\right) \\
\end{array}$ \\
\hline $\begin{array}{l}\text { の } \\
\text { 組 }\end{array}$ & \multirow{2}{*}{$\begin{array}{c}\text { YP500×YP500 } \\
\text { 又は } \\
\text { YP500×YP700 }\end{array}$} & GMAW & $\begin{array}{c}\text { 大臣認定 } \\
\text { MWLD-0015 }\end{array}$ & 0.07 & 0.4 & 1.4 & 0.3 & - & 0.19 & 590 & 660 & $\begin{array}{c}110 \\
\left(-5^{\circ} \mathrm{C}\right)\end{array}$ \\
\hline$\frac{\text { 立 }}{\tau}$ & & FCAW & $\begin{array}{c}\text { Z3313 } \\
\text { T59J1T1-1CA-X-X }\end{array}$ & 0.05 & 0.5 & 1.6 & - & Ni:0.5 & 0.19 & 600 & 640 & $\begin{array}{c}96 \\
\left(-5^{\circ} \mathrm{C}\right)\end{array}$ \\
\hline \multirow{3}{*}{ 造 } & \multirow{2}{*}{ YP400 × YP400 } & \multirow{3}{*}{ SAW } & $\begin{array}{c}\text { Z3183 } \\
\text { S532-H 該当 }\end{array}$ & 0.08 & 0.3 & 1.4 & - & $\mathrm{Ti}, \mathrm{B}$ & 0.17 & 490 & 570 & $\begin{array}{l}130 \\
\left(0^{\circ} \mathrm{C}\right)\end{array}$ \\
\hline & & & $\begin{array}{c}\text { Z3183 } \\
\text { S582-H 該当 }\end{array}$ & 0.07 & 0.2 & 1.5 & 0.2 & $\mathrm{Ti}, \mathrm{B}$ & 0.18 & 550 & 600 & $\begin{array}{l}140 \\
\left(0^{\circ} \mathrm{C}\right)\end{array}$ \\
\hline & YP500 ×YP500 & & $\begin{array}{c}\text { Z3183 } \\
\text { S624-H4 該当 }\end{array}$ & 0.10 & 0.2 & 1.4 & 0.5 & $\mathrm{Ti}, \mathrm{B}$ & 0.20 & 640 & 670 & $\begin{array}{c}110 \\
\left(-5^{\circ} \mathrm{C}\right)\end{array}$ \\
\hline \multicolumn{13}{|c|}{ 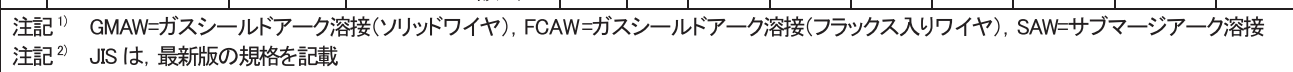 } \\
\hline
\end{tabular}




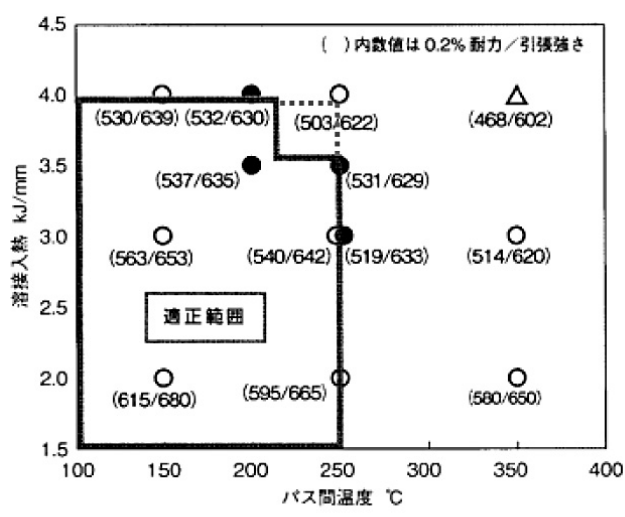

（a）ワイヤ径 1.2 Фの場合

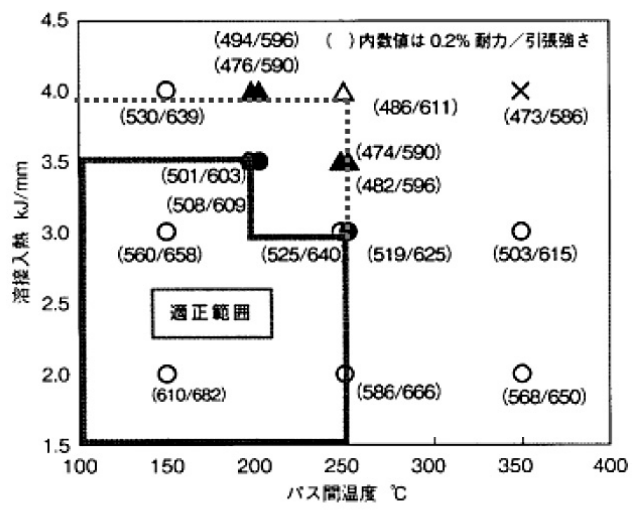

(b) ワイヤ径 1.4 Фの埸合

\begin{tabular}{|c|c|c|c|}
\hline 靯号 & & 区 分 & 板厚 \\
\hline 0 & $0.2 \%$ 耐力 $\geq 500 \mathrm{~N} / \mathrm{mm}$ & 引張強さ $590 \sim 740 \mathrm{~N} / \mathrm{mm}^{\prime}$ & \multirow{3}{*}{$25 \mathrm{~mm}$} \\
\hline$\Delta$ & $0.2 \%$ 和力 : $500 \mathrm{~N} / \mathrm{mm}$ 未满 & 引張埔さ $590 \sim 740 \mathrm{~N} / \mathrm{mm}^{\prime}$ & \\
\hline$x$ & $0.2 \%$ 的力: $500 \mathrm{~N} / \mathrm{mm}$ 末满 & 引張強さ $590 \sim 740 \mathrm{~N} / \mathrm{mm}^{2}$ 未满 & \\
\hline$\bullet$ & $0.2 \%$ 秒力 $2500 \mathrm{~N} / \mathrm{mrn}$ & 引張強さ $590 \sim 740 \mathrm{~N} / \mathrm{mm}^{2}$ & \multirow{3}{*}{$20 \mathrm{~mm}$} \\
\hline$\Delta$ & $0.2 \%$ 和力 : $500 \mathrm{~N} / \mathrm{mm}$ 未满 & 引張強さ $590 \sim 740 \mathrm{~N} / \mathrm{mm}^{\prime}$ & \\
\hline$x$ & $0.2 \%$ 响力 : $500 \mathrm{~N} / \mathrm{mm}^{\circ}$ 未满 & 引張強さ $590 \sim 740 \mathrm{~N} / \mathrm{mm}^{\prime}$ 末满 & \\
\hline
\end{tabular}

図2 YP500 用ソリッドワイヤの入熱・パス間温度の管理

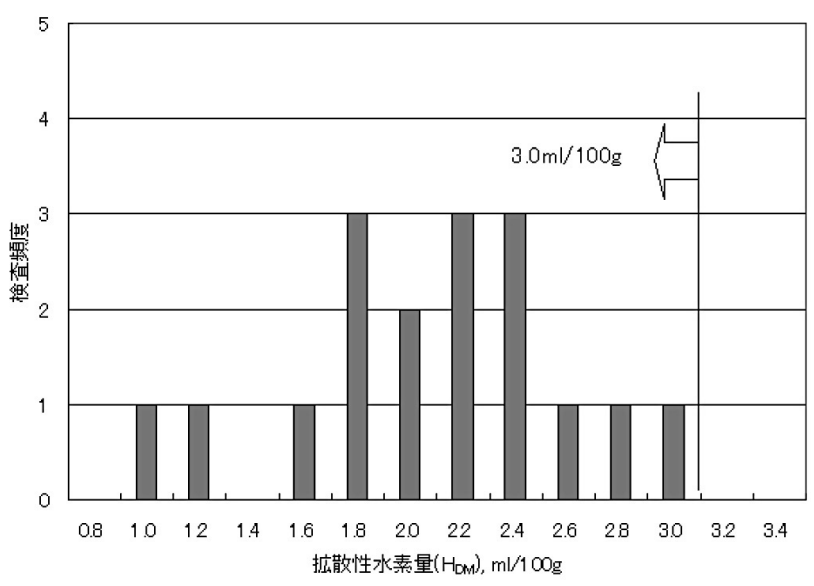

図 3 本タワー工事向けソリッドワイヤ製品の拡散性水素量検 査結果の一例

択された。

\section{(2) ソリッドワイヤの規格問題への対応}

本タワー工事用の高降伏点鋼管用溶接材料については, 該当 JIS 規格の降伏強さが，相対する鋼管の規格值と同等 以上であることが基本要件であった。しかしながら, YP500 鋼管に対応するソリッドワイヤとして，当時の JIS Z 3312 YGW21 の規格值では，その要件を満たすことがで きなかった。YP500 鋼管の降伏点下限值に対して, $10 \mathrm{~N} / \mathrm{mm}^{2}$ と僅かではあるがアンダーマッチであった。こ のような課題に対しては, 国土交通省大臣認定を取得した $590 \mathrm{~N}$ 級ワイヤを採用することで解消された。白の際, 降伏 強さ $500 \mathrm{~N} / \mathrm{mm}^{2}$ 以上を担保するため，ワイヤ径毎に適正 条件が探索された。その結果を図 2 に示す．YP500 鋼を対 象にした入熱・パス間温度の管理值上限は, 従来の降伏強 さ $440 \mathrm{~N}$ 級建築構造用鋼の場合と比べ，特にワイヤ径が $1.4 \mathrm{~mm}$ の場合には適正条件範囲が狭くなっている。その 後，当該 $1.4 \phi$ 製品においては， $1.2 \phi$ と同じ管理条件にて

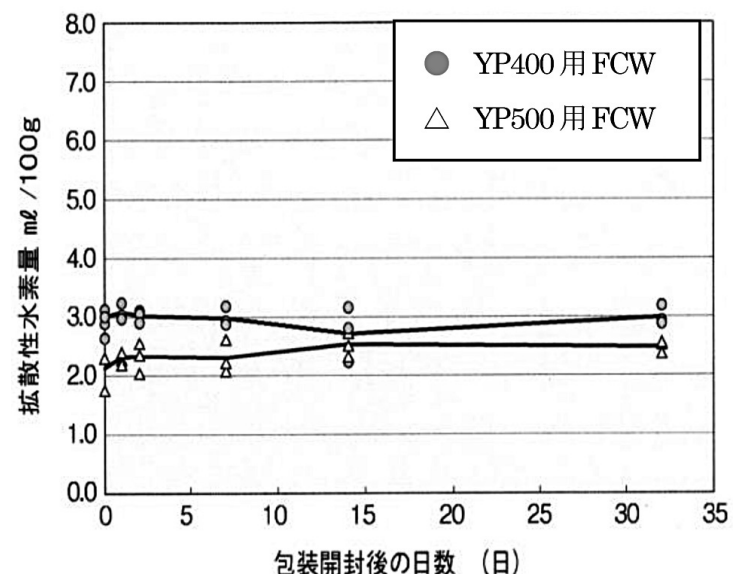

図 4 本夕ワー工事向けフラックス入りワイヤの拡散性水素量 の一例

使用が可能となるよう改善されている。

(3) $550 \mathrm{~N}$ 級フラックス入りワイヤの開発

通常, 建築鉄骨の半自動溶接施工としては, ソリッドワ イヤが主流である. 本タワー建設工事では, 分岐継手や斜 材の周溶接が多いことから，全姿勢溶接に対応できる 550 N 級フラックス入りワイヤ (JIS Z 3313 T550T1-1CA-XX）が開発された。立向溶接を想定した大入熱溶接 $(4.0 \mathrm{~kJ} / \mathrm{mm}$ 程度) に対しても, 所定の機械的特性を確保で きる特長を有する。

(4) 低水素化への取り組み

本タワーの建設工事においては, 高強度・厚肉部材の溶 接施工となることから，溶接割れを防止するために，予熱 の検討が行われた。ただ, 建方の作業環境に配慮すれば, 予 熱作業の軽減が望まれる。溶接材料面からは, ソリッドワ イヤおよびフラックス入りワイヤの全品種を対象に, 拡散 性水素量の特別仕様が設けられた。ワイヤ表面の油分量は ワイヤ送給性を担保する反面，水素源となることから，低 
表 3 YP630 円径鋼管の性能一例

\begin{tabular}{|c|c|c|c|c|c|c|c|}
\hline \multirow{3}{*}{$\begin{array}{c}\text { 径厚比 } \\
\mathrm{D} / \mathrm{t}\end{array}$} & \multicolumn{6}{|c|}{ 鋼管の機械的性質 } & \multirow{3}{*}{$\begin{array}{c}\text { 溶接継手の機械的性質 } \\
\text { 引張特性 } \\
\text { 引張強さ } \\
\left(\mathrm{N} / \mathrm{mm}^{2}\right) \\
\end{array}$} \\
\hline & \multicolumn{4}{|c|}{ 引張特性 } & シャルピー衝撃特性 & 溶接割れ感受性組成 & \\
\hline & $\begin{array}{c}\text { 降伏点又は耐力 } \\
\left(\mathrm{N} / \mathrm{mm}^{2}\right)\end{array}$ & $\begin{array}{l}\text { 引張強さ } \\
\left(\mathrm{N} / \mathrm{mm}^{2}\right)\end{array}$ & $\begin{array}{c}\text { 降伏比 } \\
(\%)\end{array}$ & $\begin{array}{c}\text { 伸び } \\
(\%)\end{array}$ & $\begin{array}{c}\text { vE } 0^{\circ} \mathrm{C} \\
(\mathrm{J})\end{array}$ & $\begin{array}{c}\mathrm{P}_{\mathrm{CM}}{ }^{*} \\
(\%)\end{array}$ & \\
\hline$\geqq 10$ & $\geqq 630$ & $780 \sim 930$ & $\leqq 90$ & $\geqq 16$ & $\geqq 47$ & $\leqq 0.30$ & $\geqq 780$ \\
\hline
\end{tabular}

表 4 YP630 円形鋼管用溶接材料の性能一例

\begin{tabular}{|c|c|c|c|c|c|c|c|c|c|c|c|c|}
\hline \multirow[b]{2}{*}{ 溶接法 } & \multirow[b]{2}{*}{ JIS規格 } & \multicolumn{7}{|c|}{ 溶接金属の化学成分の一例 (\%) } & \multicolumn{4}{|c|}{ 溶接金属の機械的性質の一例 } \\
\hline & & C & $\mathrm{Si}$ & $\mathrm{Mn}$ & P & s & $\mathrm{Ni}$ & Mo & $\begin{array}{l}0.2 \% \text { 耐力 } \\
\left(\mathrm{N} / \mathrm{mm}^{2}\right)\end{array}$ & $\begin{array}{l}\text { 引張強さ } \\
\left(\mathrm{N} / \mathrm{mm}^{2}\right)\end{array}$ & $\begin{array}{l}\text { 伸び } \\
(\%)\end{array}$ & $\begin{array}{c}\text { 吸収 } \\
\text { エネルギー } \\
(\mathrm{J})\end{array}$ \\
\hline SAW & Z3183 S80J4-H4該当 & 0.09 & 0.35 & 1.68 & 0.012 & 0.005 & 2.53 & 0.75 & 840 & 910 & 18 & $\begin{array}{c}-60^{\circ} \mathrm{C} \\
100 \\
-80^{\circ} \mathrm{C} \\
95\end{array}$ \\
\hline GMAW & Z3312 G 78 A 2 U C N4M4T & 0.08 & 0.38 & 1.25 & 0.009 & 0.011 & 2.22 & 0.63 & 710 & 830 & 22 & $\begin{array}{c}0^{\circ} \mathrm{C} \\
95\end{array}$ \\
\hline
\end{tabular}

水素化の実現のために油量が厳重管理された。例えば，ソ リッドワイヤについては, 図 3 に示すように拡散性水素量 が $3 \mathrm{ml} / 100 \mathrm{~g}$ 以下に管理された製品が出荷された。

一方，フラックス入りワイヤでは，開封初期段階での低 水素化に取り組んだ。製造工程などの見直しにより，図 4 に示すように拡散性水素量として $4 \mathrm{ml} / 100 \mathrm{~g}$ 以下を実現 した。

\section{4. ゲイン塔の建設工事}

\section{1 降伏点 $630 \mathrm{~N} / \mathrm{mm}^{2}$ 級鋼管について}

ゲイン塔には，降伏点 $400,500 \mathrm{~N} / \mathrm{mm}^{2}$ 級鋼だけでなく, より高強度な引張強さ $780 \mathrm{~N} / \mathrm{mm}^{2}$ 級鋼 (以下, HT780 鋼) による, 降伏点 $630 \mathrm{~N} / \mathrm{mm}^{2}$ 級（以下, YP630) 円径鋼管が 使用された。最大板厚 $80 \mathrm{~mm}$ までの YP630 厚肉円形鋼管 が建築構造物に採用されるのは，国内初となる。

阪神・淡路大震災以降, 巨大地震時の倒壊防止を目的と して, 塑性変形能力の観点での低降伏比化や, 破壊の起点 となりやすい溶接熱影響部 (Heat Affected Zone, 以下 HAZ）での良好な勒性といった，建築構造物の耐震安全性 向上に関わる特性が, 建築用鋼材に求められるようになっ た. また，良好な溶接性を確保するため，鋼板成分の低 $\mathrm{P}_{\mathrm{CM}}$ 化が望まれている.この状況を踏まえ, 表 3 の例に示す, 従 来鋼板と比較して HAZ 鞀性に優れ，降伏比を低く抑えた YP630 円径鋼管が開発され, ゲイン塔の一部に適用されて いる⿱亠乂.

\section{2 降伏点 $630 \mathrm{~N} / \mathrm{mm}^{2}$ 級鋼管用の溶接材料}

表 4 の例で示す YP630 鋼管用溶接材料は，1耐割れ性 の向上，(2)高靱性化，を大きなキーワードとして開発され ており，以下にその特長について述べる.

\section{(1) 耐割れ性の向上}

YP630 鋼の溶接時に問題となる割れは，HAZ の硬化ある いは溶接材料の拡散性水素に起因する低温割れであり, 溶 接材料面からは, 強度レベル, 積層厚さ, 拡散性水素量の 影響に関する検討が進められた。式 (1) は，溶接金属の強 度, 積層厚さ, 拡散性水素量から, 多層溶接金属の割れ停
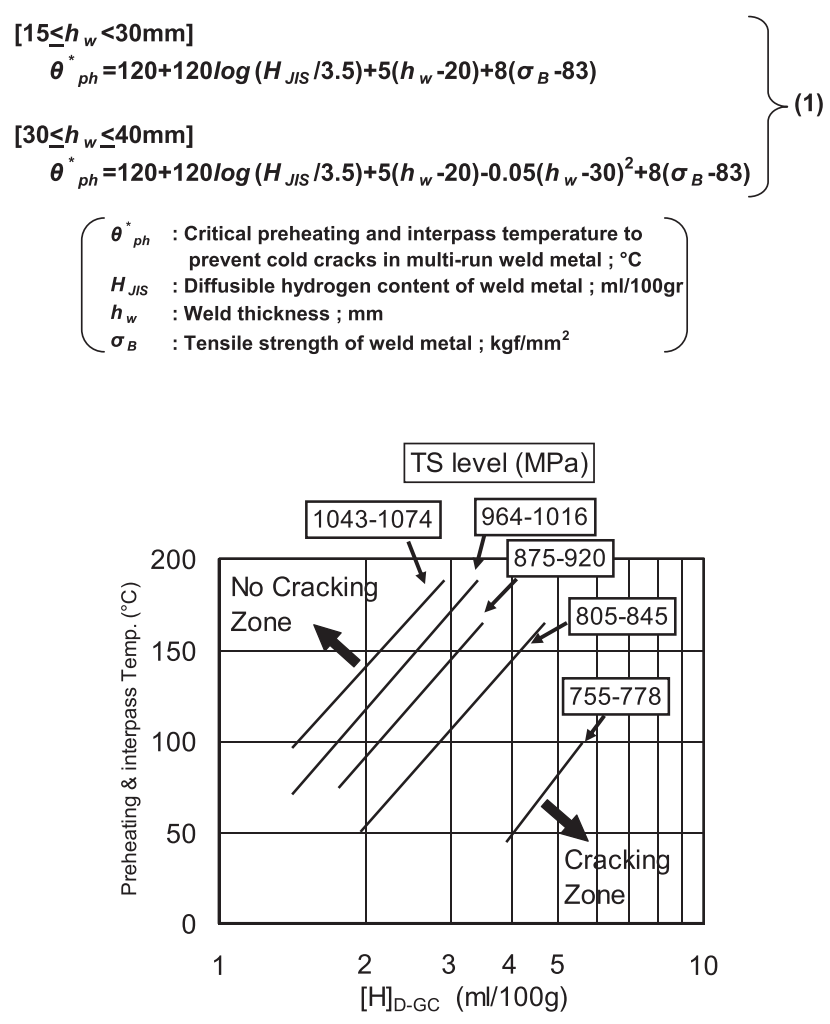

図 5 多層溶接金属の低温割れに及ぼす拡散性水素量亡強度の 影響 (SAW)

止最低予熱温度を計算する推定式を示したもので, 引張強 さレベル $590 \sim 900 \mathrm{~N} / \mathrm{mm}^{2}$, 拡散性水素量レベル 0.1〜 $40 \mathrm{~mL} / 100 \mathrm{~g}$ (グリセリン法)に適用可能である5). 図 5 は, 厚板での拘束多層溶接割れ試験結果を示す。この試験で は, 溶接金属の強度と拡散性水素レベルを変化させている が, 式 (1) 同様に拡散性水素量が低いほど, また強度が低 いほど, 割れを防止するための予熱温度を低くできること がわかる6.

SAW 材料における一層の低水素化は, 図 6 に示すボン ドフラックスへの炭酸塩の添加によって, アーク雲囲気中 の水素分圧を抑えることで, 溶接金属の極低水素化を実現 した7). 


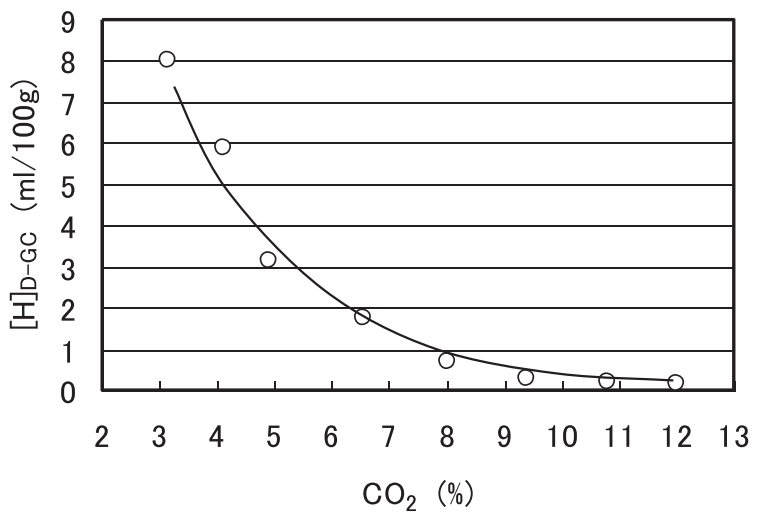

図 6 ボンドフラックス中の $\mathrm{CO}_{2}$ 量と溶着金属の拡散性水素量 の関係

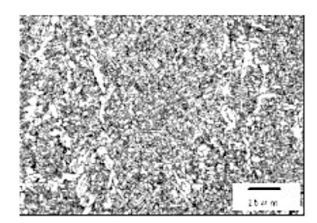

$\mathrm{YS} \fallingdotseq 500 \mathrm{MPa}$

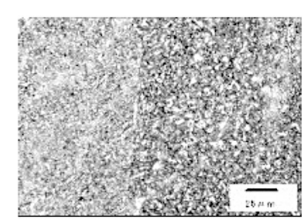

$\mathrm{YS} \fallingdotseq 830 \mathrm{MPa}$

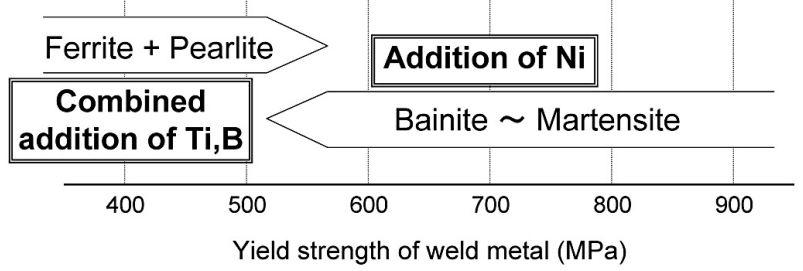

図 7 強度別の靱性向上手段

\section{(2) 高勒性化}

図 7 に示すように, YP550 鋼程度までの溶接材料では, Ti-B 複合添加によって高勒性化が図られているが, YP600 鋼以上の溶接金属ミクロ組織はベイナイト〜マルテンサ イトであり，フェライト微細化技術である Ti-B 系の採用 はできない，基本的には，変態点の低下によるミクロ組織 微細化とマトリックスを強靶化する目的で，Ni が活用さ れている. その効果の一例を図 8 に示すが, 遷移曲線は $\mathrm{Ni}$ 量の増加に伴って低温側へと移行している.

HT780 鋼用高勒性溶接材料の溶接金属化学成分は, C-SiMn-2.0〜3.5Ni-(Cr)-Mo 系が採用さており, GMAW 材料に ついては, 低 $\mathrm{C}$, 高 $\mathrm{Ni}$ 系とすることによって溶接金属の強 䩚化が, SAW 材料については, 高 Ni 系ワイヤと低酸素溶 接金属が得られる, 高塩基性のボンドフラックスとの組合 せによって，強鞀化が図られている。

ただし, 図 9 に示す SAW 材料における例8のように, こ の強度クラスの溶接材料の溶接金属強度は, 溶接時の冷却 速度と密接に関係しており, 所定の強度を得るためには, 施工条件の管理が必要である。

\section{(3) 溶接施工管理}

YP630 鋼管は，優れた耐割れ性および良好な機械的性質 を両立した溶接金属を得るため, 表 5 に示す例のように厳 密な管理のもとで，施工が行われた。

SAW 材料は, 低温割れ防止のため, 溶着金属の拡散性水 素量が極めて低く設計されているが, HT780 鋼としては異

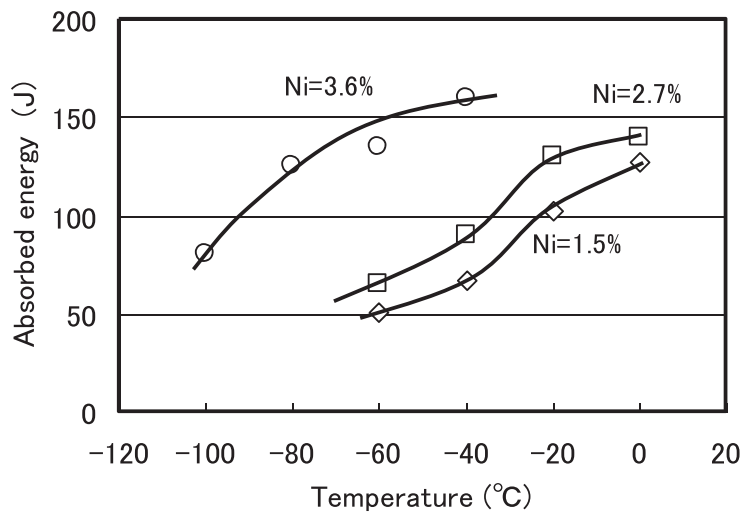

図 8 溶接金属の靯性に及ぼす $\mathrm{Ni}$ 添加量の影響（GMAW）

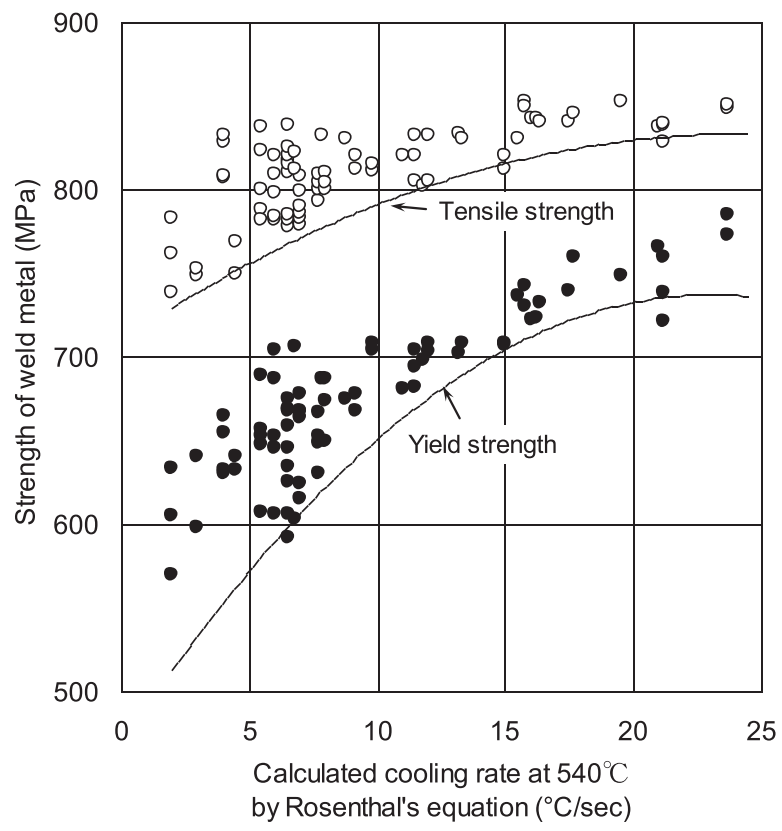

図 9 溶接金属の強度に及ぼす冷却速度の影響（SAW）

例の極厚板であるため, 予熱・パス間温度の管理値下限は 裕度を持って $125^{\circ} \mathrm{C}$ とした。た, 溶接直後熱処理として 150 $200^{\circ} \mathrm{C}$ を $1 \sim 2$ 時間行うことにより, 溶接金属中の拡 散性水素を逃すことで, 耐低温割れ性を更に向上させる施 工を実施した。強度確保には, 溶接金属の冷却速度が遅く なることを防ぐため, 予熱・パス間温度の管理值上限を $200^{\circ} \mathrm{C}$ とし, 入熱の上限は $10.0 \mathrm{~kJ} / \mathrm{mm}$ 以下とした. 溶接条 件の一例を表 6 に, 断面マクロ組織の一例を写真 1 に示 す.

GMAW 材料は, 強度確保のため, 溶接施工指針9ににおい て, 低入熱 $(3.0 \mathrm{~kJ} / \mathrm{mm}$ 以下 $)$, 低パス間温度 $\left(150^{\circ} \mathrm{C}\right.$ 以下 $)$ での管理が必要とされており, 現場溶接施工に則した検証 において,より詳細に適正電流・電圧が確認されている10). また, ゲイン塔は設置高さが $500 \mathrm{~m}$ を超えており, 設置位 置での組み立て溶接は, 厳しい気象条件下で行われること となるため, 予熱・パス間温度管理や防風対策など, 安定 した溶接部の品質が得られる施工管理は, 困難が予測され た。この問題を解決するため採用されたのが，リフトアッ プ工法であり, シャフト空洞部の地上付近でゲイン塔の組 み立てを行うことができたため, 安定した溶接部の品質を 
表 5 YP630 鋼用溶接材料の施工管理一例

\begin{tabular}{|c|c|c|c|c|c|}
\hline 溶接法 & JIS規格 & 板厚 & 予熱・パス間温度 & 溶接入熱 & 備考 \\
\hline \multirow{2}{*}{ SAW } & \multirow{2}{*}{ Z3183 S80J4-H4該当 } & $30 \sim 50 \mathrm{~mm}$ & $100 \sim 200^{\circ} \mathrm{C}$ & \multirow{2}{*}{$\leqq 10.0 \mathrm{~kJ} / \mathrm{mm}$} & \multirow{2}{*}{$\begin{array}{l}\text { フララックス乾燥: } 250 \sim 350^{\circ} \mathrm{C} \times 1 \mathrm{hr} . \\
\text { 電源極性 : AC }\end{array}$} \\
\hline & & $50 \sim 80 \mathrm{~mm}$ & $125 \sim 200^{\circ} \mathrm{C}$ & & \\
\hline \multirow[t]{2}{*}{ GMAW } & \multirow[t]{2}{*}{ Z3312 G 78 A 2 U C N4M4T } & $30 \sim 50 \mathrm{~mm}$ & $\begin{array}{r}75 \sim 150^{\circ} \mathrm{C} \\
100 \sim 10^{\circ} \mathrm{C}\end{array}$ & \multirow[t]{2}{*}{$\leqq 3.0 \mathrm{~kJ} / \mathrm{mm}$} & $\begin{array}{l}\text { 電流: } 250 \sim 280 \mathrm{~A} \\
\text { 雷厅: } 32 \text { V以下 }\end{array}$ \\
\hline & & $50 \sim 80 \mathrm{~mm}$ & & & \\
\hline
\end{tabular}

表 6 YP630 鋼の溶接条件一例

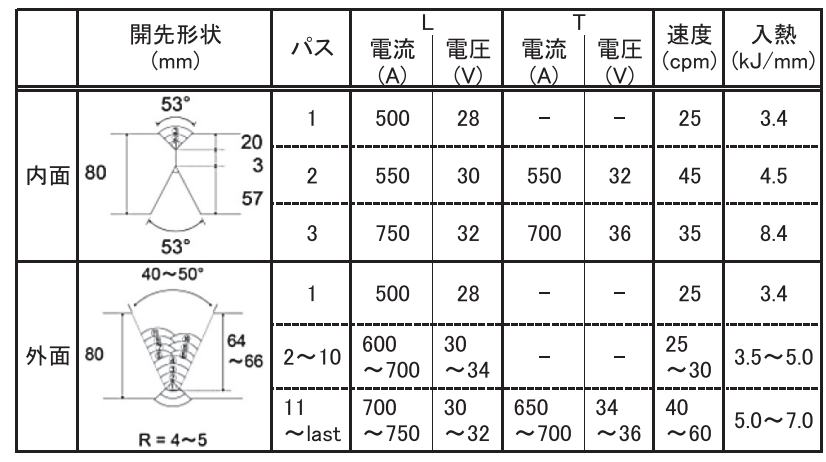

確保できた。

\section{5. おわり}

東京スカイッリーは, 高降伏点鋼や低降伏比鋼など新し い高張力鋼の極厚鋼板が採用されており，溶接部が複雑な 形状となる鋼管卜ラス構造であるため, 健全で必要性能を 满足する溶接継手を作製することが難しく, 現地組み立て においては, 高所での厳しい環境下での溶接が必要となる 建築構造物だった。これらの課題に対して, 溶接材料面で は，適正な成分添加による性能の確保，フラックス入りワ イヤの適用による作業性の向上などが図られ, 施工管理面 では，溶接条件や予熱・パス間温度の管理，防風対策など が取り入れられた。これらは，長年積み重ねてきた溶接技 術の粋を集めて, 初めて可能となった溶接施工の集大成と 言える. 本タワーの建設を通して新しく開発された技術や 施工管理上の知見は, 今後更に磨き上げられて, 一般構造 物の溶接へも活用されることが期待される.

加えて, 本タワーのような歴史に残る巨大建造物の建設 において, 溶接が担う役割が様々なメディアに取り上げら れた. 溶接材料が, 建造物に占める重量割合は2 3\% と少 ないが, 極めて重要な技術分野であることを, 日常は溶接 に関わらない人たちにも, 興味を持って知って頂ける, 非

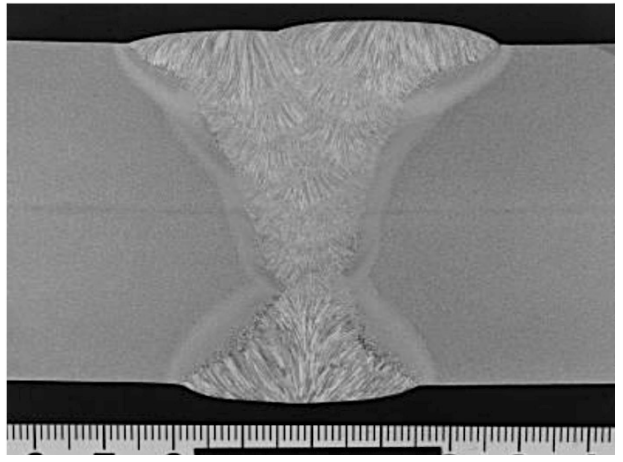

写真 1 YP630 鋼の溶接金属断面マク口組織（板厚 50 mm）

常に素晴らしい機会だったと思う。

今回，歴史的な建造物の建設に関われたことに感謝し， 今後の溶接技術の更なる発展に貢献したい。

\section{参考文献}

1）鈴木孝彦ほか：新日鉄技報第 387 号（2007）64 2007年.

2）鈴木孝彦・村田義明：配管技術54巻 (2012) 2 号, 17, 2012 年 2 月.

3) 村田義明：第12回鉄鋼材料と鋼構造に関するシンポジウ 厶，2012年。

4) 山口徹雄ほか：HAZ 靫性に優れた建築構造用低 YR 型 $780 \mathrm{MPa}$ 級円径鋼管の特性と組織制御技術, 神戸製鋼技報, 61-2 (2011) 16-19.

5) 矢竹丘ほか：鋼材の溶接遅れ割れの研究 (第 3 報), 溶接学 会誌，50-3 (1981) 291-296.

6) N. Okuda et al.: HYDROGEN INDUCED CRACKING SUSCEPTIBILITY OF WELD METAL, IIW-No.II-1072-86 (1986).

7）長谷薰ほか：造船の建造方法を変えた片面サブマージアー ク溶接法の開発と発展, 神戸製鋼技報, 50-3 (2000) 70-73.

8) 原則行：溶接材料面から見た溶接施工管理について, 溶接 技術， 9 (1999) 89-93.

9）建築構造用鋼性能鋼管 KSAT630，溶接施工指針，神戸製鋼 所 (2007).

10）中平和人ほか：第二吉本ビルディング 第 2 回 建築構造用 鋼性能 $780 \mathrm{~N} / \mathrm{mm}^{2}$ 鋼材（HT780）の溶接施工，鉄鋼技術, 17-193 (2004) 56-65. 